Volume 10 Issue 2, April-June 2016: pp. 221-412. Copyright (c) 2015-2016 FIAT JUSTISIA. Faculty of Law, Lampung University, Bandarlampung, Lampung, Indonesia.

ISSN: 1978-5186 | e-ISSN: 2477-6238.

Open Access: http://jurnal.fh.unila.ac.id/index.php/fiat

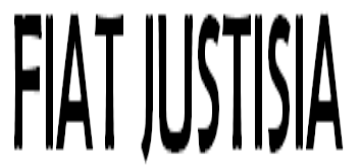

Fiat Justisia is licensed under a Creative Commons Attribution 4.0 International License, which permits unrestricted use, distribution, and reproduction in any medium, provided the original work is properly cited.

\title{
PENEGAKAN HUKUM TERHADAP TINDAK PIDANA PENYALAHGUNAAN IZIN TINGGAL KEIMIGRASIAN (Studi Kantor Imigrasi Kelas I Bandar Lampung)
}

\author{
Law Enforcement on Crime of Abuse of Permission to Stay \\ Immigration \\ (Study of Class I Immigration Office Bandar Lampung)
}

\author{
Albert Sanusi \\ Kantor Imigrasi Kelas I Bandar Lampung \\ email: albert_sanusi@yahoo.com
}

\begin{abstract}
The presence of foreigners in the area of Lampung is increasing rapidly. But most foreigners are missing or doing activities that are inconsistent with the purpose of providing immigration permit. Results of research and discussion show that law enforcement criminal act of abuse of a residence permits the immigration done by administrative measures and actions pro-justice immigration. Obstacles to the enforcement of the law against the crime of abuse of a residence permit immigration because the number of immigration officers who conduct surveillance and monitoring of the presence of foreigners is still lacking, a lack of coordination and cooperation across sectors, the lack of investigators Immigration master a foreign language other than English, the limited number of facilities operational support and Lampung people that are non-cooperative which reports or complaints from the public about the existence or activities of foreigners who are nearby are very limited. Suggestions from this study are the immigration officers should increase oversight of the existence and activities of foreigners. Pro-justice in law enforcement actions should be effected, in order to ensure a deterrent effect to the perpetrators and other foreigners so as not committing a crime similar immigration. In addition, Lampung people are expected to cooperate with immigration officials to make a complaint about the existence or activities of foreigners who are nearby.
\end{abstract}

Keywords: Law Enforcement, Residence Permit, Immigration 


\begin{abstract}
Abstrak
Kehadiran orang asing di wilayah Lampung meningkat dengan cepat. Tetapi kebanyakan orang asing yang hilang atau melakukan kegiatan yang tidak sesuai dengan tujuan memberikan izin keimigrasian. Hasil penelitian dan pembahasan menunjukkan bahwa penegakan hukum tindak pidana penyalahgunaan tempat tinggal izin imigrasi dilakukan oleh tindakan administratif dan tindakan pro-keadilan imigrasi. Kendala terhadap penegakan hukum terhadap tindak pidana penyalahgunaan dari imigrasi izin tinggal karena jumlah petugas imigrasi yang melakukan pengawasan dan pemantauan kehadiran orang asing masih kurang, kurangnya koordinasi dan kerjasama lintas sektor, kurangnya penyidik Master imigrasi bahasa asing selain bahasa Inggris, terbatasnya jumlah fasilitas pendukung operasional dan orang Lampung yang non-kooperatif yang melaporkan atau keluhan dari masyarakat tentang keberadaan atau kegiatan orang asing yang berada di dekatnya sangat terbatas. Saran dari penelitian ini adalah petugas imigrasi harus meningkatkan pengawasan terhadap keberadaan dan kegiatan orang asing. Pro-keadilan dalam tindakan penegakan hukum harus dilakukan, untuk memastikan efek jera kepada pelaku dan orang asing lainnya agar tidak melakukan kejahatan imigrasi yang sama. Selain itu, orang Lampung diharapkan untuk bekerja sama dengan petugas imigrasi untuk membuat keluhan tentang keberadaan atau kegiatan orang asing yang berada di dekatnya.
\end{abstract}

\title{
Kata Kunci: Penegakan hukum, Izin Tinggal, Imigrasi
}

\section{A. Pendahuluan}

Dalam era globalisasi dan perdagangan bebas telah membawa dampak pada peningkatan lalu lintas orang semakin tinggi. Fenomena ini sudah menjadi perhatian negara-negara di dunia termasuk Indonesia sebab setiap negara-negara di dunia mempunyai kedaulatan untuk mengatur lalu lintas orang yang akan masuk dan keluar wilayah negaranya. Dampak yang timbul semakin bervariasi, menghadapi kenyataan ini masing-masing negara menyikapi dengan hati-hati dan bijaksana supaya tidak berdampak negatif kepada sektor bisnis perekonomian suatu negara atau hubungan yang disharmonis antarnegara, sehingga pedoman berhubungan antar satu dengan yang lain seoptimal mungkin disesuaikan dengan kondisi sosial politik masing-masing negara.

Dampak yang ditimbulkan dari globalisasi yaitu, perdagangan narkotika antarnegara, aksi-aksi terorisme yang mengancam keamanan dan ketertiban dunia, perdagangan manusia (human trafficking), penyelundupan manusia (people smuggling), pencucian uang (money laundering), imigran gelap, perdagangan senjata dan lain sebagainya. Dari contoh dampak negatif 
di atas, dapat digolongkan sebagai aksi kejahatan yang terorganisir atau sering disebut TOC (Transnational Organized Crimes). Kejahatan tersebut bukan hanya mengancam kedaulatan Negara Indonesia sendiri, tetapi juga mengancam dan mengganggu ketentraman dan kedaulatan seluruh Negara di dunia.

Untuk meminimalisasikan dampak negatif yang timbul akibat era globalisasi dan dinamika mobilitas manusia, baik warga negara Indonesia maupun orang asing yang keluar, masuk dan tinggal di wilayah Indonesia, maka diperlukan suatu lembaga yang mengatur masalah tentang keluar masuknya orang ke wilayah negara Republik Indonesia, yaitu Kantor Imigrasi.

Kantor Imigrasi adalah suatu lembaga yang mengatur masalah tentang keluar masuknya orang ke wilayah negara Republik Indonesia. Permasalahan keimigrasian diatur dalam Undang-Undang Nomor 6 Tahun 2011 tentang Keimigrasian. Di mana dalam Pasal 1 angka 1 Undang-Undang Nomor 6 Tahun 2011 tentang Keimigrasian disebutkan bahwa "Keimigrasian adalah hal ihwal lalu lintas orang masuk atau keluar wilayah Indonesia serta pengawasannya dalam rangka menjaga tegaknya kedaulatan negara".

Pengaturan bidang keimigrasian (lalu lintas keluar masuk) suatu negara, berdasarkan hukum internasional menurut Ramadhan K.H. dan Abrar Yusra merupakan hak dan wewenang suatu negara. Dengan perkataan lain, merupakan salah satu indikator kedaulatan suatu negara. ${ }^{1}$ Imigrasi juga mempunyai peran diberbagai bidang kehidupan berbangsa dan bernegara seperti bidang ekonomi, politik, hukum, dan keamanan. Tindakan atau sanksi yang dapat diberikan kepada orang asing yang melakukan tindak pidana keimigrasian menurut Moh. Arif dibagi atas 2 (dua) bentuk yaitu: 1) melalui tindakan keimigrasian; dan 2) melalui proses peradilan. ${ }^{2}$

Diperlukan suatu tindakan untuk mendetensikan seorang asing dalam ruang detensi Imigrasi Bandar Lampung. Orang asing yang tinggal di Propinsi Lampung akan dilakukan pengawasan oleh Kantor Imigrasi untuk menjaga suasana yang kondusif, contohnya di bidang keamanan perlu diwaspadai masuknya jaringan terorisme internasional, apabila dalam prosedur pengawasan ditemukan pelanggaran dan kejahatan, maka terhadap orang asing tersebut akan dikenakan sanksi pidana sesuai dengan peraturan perundang-undangan yang berlaku di Indonesia.

${ }^{1}$ K.H. Ramadhan dan Yusra, Abrar. (2005). Lintas Sejarah Imigrasi Indonesia. Jakarta: Direktorat Jenderal Imigrasi, p. 13.

2 Arif, Moh.(1997). Suatu Pengantar Keimigrasian di Indonesia. Jakarta: Pusdiklat Departemen Kehakiman, p. 113. 
Berdasarkan latar belakang di atas, maka permasalahan dalam penelitian ini dirumuskan sebagai berikut:

1. Bagaimanakah penegakan hukum terhadap tindak pidana penyalahgunaan izin tinggal keimigrasian?

2. Mengapa terjadi hambatan dalam penegakan hukum terhadap tindak pidana penyalahgunaan izin tinggal keimigrasian?

Penelitian ini menggunakan pendekatan yuridis normatif dan yuridis empiris. Pendekatan yuridis normative dilakukan untuk memahami persoalan dengan tetap berada atau bersandarkan pada lapangan atau kajian ilmu hukum, sedangkan pendekatan yuridis empiris sebagai data pendukung dilakukan untuk memperoleh kejelasan dan pemahaman dan permasalahan penelitian berdasarkan realitas yang ada atau studi kasus ${ }^{3}$ yang diperoleh dari hasil wawancara di Kantor Imigrasi Kelas I Bandar Lampung dengan Responden yakni Kepala Kantor Imigrasi Kelas 1 Bandar Lampung dan Kepala Seksi Pengawasan dan Penindakan Keimigrasian Kantor Imigrasi Kelas 1 Bandar Lampung untuk memberikan gambaran atau hal-hal yang berkaitan dengan tindak pidana penyalahgunaan izin tinggal keimigrasian.

\section{B. Pembahasan}

\section{Gambaran Umum Kantor Imigrasi Kelas I Bandar Lampung}

Pada Tahun 1959 kantor Imigrasi di bentuk dan diresmikan oleh Kepala Kantor Wilayah Palembang dan diberi nama kantor Imigrasi Lampung yang sebelumnya merupakan bagian dari wilayah kerja kantor Imigrasi Palembang. Pada tahun 1972 kantor Imigrasi Lampung yang beralamat di jalan Sarinarwa No. 1 Teluk Betung di pindah ke jalan Diponegoro 133 Bandar Lampung, dan kemudian kantor Imigrasi Lampung di ganti namanya menjadi kantor Imigrasi kelas II Tanjung Karang dengan wilayah kerja meliputi: Kota Tanjung Karang/Teluk Betung, Kabupaten Lampung Selatan, Kabupaten Lampung Utara, Kabupaten Lampung Tengah. Pada tahun 1986 kantor Imigrasi Tanjung Karang berganti nama menjadi kantor Imigrasi Bandar Lampung dengan klasifikasi kantor Imigrasi Kelas II.

Pada tahun 2004 seiring dengan meningkatnya volume kegiatan dan beban kerja dalam pelayanan keimigrasian pada Kantor Imigrasi Kelas I Bandar Lampung yang sebelumnya klasifikasi kelas II berubah menjadi kelas I dan Kantor Imigrasi Kelas I Bandar Lampung sekarang beralamatkan di jalan $\mathrm{Hj}$. Haniah Nomor 3 Cut Mutia Bandar Lampung.

Dalam perkembangannya seiring dengan dinamika pembangunan di daerah Propinsi Lampung, terjadi beberapa perubahan atau Pemekaran Wilayah. Hal ini berdampak pula terhadap perkembangan tugas dan fungsi

\footnotetext{
${ }^{3}$ Soekanto, Soerjono. (1986). Pengantar Penelitian Hukum. Jakarta: Rineka Cipta, p. 32.
} 
keimigrasian yang dijalankan oleh kantor Imigrasi Bandar Lampung. Dengan dibentuknya kantor Imigrasi kelas III Kalianda Lampung Selatan dan kantor Imigrasi kelas III Kotabumi Lampung Utara, maka sebagian wilayah kerja kantor Imigrasi Kelas I Bandar Lampung berkurang.

Saat ini setelah terjadinya perubahan dan pemekaran Wilayah di daerah Propinsi Lampung maka wilayah Kantor Imigrasi Bandar Lampung meliputi 4 Kabupaten dan 2 Kotamadya yang membawahi 90 Kecamatan.

Tabel 1.

Wilayah Kerja Kantor Imigrasi Kelas I Bandar Lampung

\begin{tabular}{|l|l|l|}
\hline NO & \multicolumn{1}{|c|}{ Wilayah kerja } & \multicolumn{1}{|c|}{ Kecamatan } \\
\hline 1 & Kota Metro & 5 Kecamatan \\
2 & Kota Bandar Lampung & 20 Kecamatan \\
3 & Kabupaten Lampung Tengah & 28 Kecamatan \\
4 & Kabupaten Tanggamus & 20 Kecamatan \\
5 & Kabupaten Pringsewu & 8 Kecamatan \\
6 & Kabupaten Pesawaran & 9 Kecamatan \\
\hline Jumlah & 2 Kotamadya dan 4 Kabupaten & 90 Kecamatan \\
\hline
\end{tabular}

Sumber : Kantor Imigrasi Kelas I Bandar Lampung.

Keberadaan Kantor Imigrasi Kelas I Bandar Lampung dirasakan sudah sejalan dengan upaya-upaya Pemerintah Daerah Propinsi Lampung dalam memacu pembangunan wilayahnya. Hal ini terutama dalam rangka memacu industrialisasi serta perdagangan barang dan jasa. Terlebih penduduk di wilayah kerja Kantor Imigrasi Kelas I Bandar Lampung jumlahnya cukup signifikan untuk diberikan pelayanan keimigrasian. Melihat potensi tersebut maka sejak lama telah disiapkan sistem pelayanan yang memadai agar dapat menampung kebutuhan masyarakat terhadap pelayanan keimigrasian. Hal tersebut dilakukan mengingat dalam beberapa tahun terakhir volume pelayanan di Kantor Imigrasi Kelas I Bandar Lampung semakin meningkat, terutama yang berkenaan dengan pelayanan pembuatan Surat Perjalanan Republik Indonesia (SPRI) yang hampir 
mencapai rata-rata 24000 paspor setiap tahunnya (per bulan \pm 2000 , per minggu \pm 500 , per hari \pm 100 ).

Peningkatan pelayanan tersebut juga diimbangi dengan pelaksanaan fungsi pengawasan keimigrasian secara terencana. Untuk itu Kantor Imigrasi Kelas I Bandar Lampung telah menyiapkan sarana dan prasarana pengawasan keimigrasian dengan membangun tempat karantina yang sesuai dengan kebutuhan.

Tugas pokok Kantor Imigrasi Kelas I Bandar Lampung adalah melaksanakan sebagian tugas pokok dan fungsi Kementerian Hukum dan Hak Asasi Manusia (HAM) di bidang Keimigrasian di wilayah Bandar Lampung. Dalam menyelenggarakan tugas tersebut kantor Imigrasi kelas I Bandar Lampung mempunyai fungsi:

a. melaksanakan tugas dibidang tata usaha;

b. melaksanakan tugas keimigrasian dibidang informasi dan sarana komunikasi keimigrasian;

c. melaksanakan tugas keimigrasian dibidang lalu lintas keimigrasian;

d. melaksanakan tugas keimigrasian dibidang status keimigrasian;

e. melaksanakan tugas keimigrasian dibidang pengawasan dan penindakan keimigrasian.

Berikut ini tugas-tugas pokok dari setiap Pejabat Imigrasi:

a. Kepala Kantor Imigrasi

Mengkoordinasikan pelaksanaan di bidang keimigrasian meliputi informasi dan sarana komunikasi, lintas antar negara dan perizinan, pengendalian status serta melakukan pengawasan dan penindakan terhadap mereka yang melanggar ketentuan keimigrasian berdasarkan peraturan perundang-undangan yang berlaku dalam rangka tertibnya pelaksanaan tugas di bidang keimigrasian.

\section{b. Kepala Sub Bagian Tata Usaha}

Mengkoordinasikan penyelenggaraan Tata Usaha dan Rumah Tangga Kantor Imigrasi Kelas I yang antara lain meliputi urusan surat menyurat, kepegawaian, keuangan, perlengkapan dan rumah tangga serta memberikan pelayanan administrasi di lingkungan Kantor Imigrasi Kelas I sesuai dengan peraturan perundang-undangan yang berlaku.

\section{c. Kepala Urusan Keuangan}

Melaksanakan urusan keuangan yang meliputi anggaran belanja rutin dan pembangunan di lingkungan kantor sesuai dengan ketentuan peraturan perundang-undangan yang berlaku. 


\section{d. Kepala Urusan Kepegawaian}

Melaksanakan urusan kepegawaian yang meliputi formasi mutasi, pemberhentian dan pemensiunan di lingkungan kantor sesuai dengan peraturan perundang-undangan yang berlaku.

\section{e. Kepala Urusan Umum}

Melaksanakan urusan umum yang meliputi surat menyura, perlengkapan dan rumah tangga di lingkungan kantor sesuai dengan peraturan perundang-undangan yang berlaku.

\section{f. Kepala Seksi Lalu Lintas Keimigrasian}

Melakukan kegiatan keimigrasian yang meliputi pemberian perlintasan, pemberian pemohonan dokumen perjalanan izin berangkat / kembali bagi warga negara asing atau warga negara Indonesia serta kegiatan dalam hal perjalanan, pendaratan, urusan haji, pengiriman tenaga kerja Indonesia ke luar negeri, pengurusan anak kapal dan izin masuk darurat sesuai dengan peraturan perundang-undangan yang berlaku dalam rangka menunjang kelancaran pelayanan keimigrasian.

\section{g. Kepala Sub Seksi Perizinan Keimigrasian}

Melakukan pemberian dokumen perjalanan, izin berangkat dan izin kembali bagi WNA maupun WNI sesuai dengan peraturan perundangundangan yang berlaku guna tertibnya WNA / WNI yang keluar maupun masuk negara Indonesia.

\section{h. Kepala Sub Seksi Lintas Batas}

Memberikan perizinan Lintas Batas bagi warga negara asing yang hendak masuk ke Indonesia maupun warga negara Indonesia yang hendak pergi ke luar Indonesia sesuai perjanjian Lintas Batas yang telah ditetapkan dalam rangka tertibnya keluar masuk melalui pos perbatasan.

\section{i. Kepala Seksi Pengawasan dan Penindakan Keimigrasian}

Melakukan pengawasan dan penindakan serta penanggulangan terhadap WNA dan pemukim gelap yang melanggar ketentuan Keimigrasian di lingkungan kantor sesuai dengan peraturan perundang-undangan yang berlaku dalam rangka menertibkan WNA yang masuk ke wilayah Republik Indonesia. 


\section{j. Kepala Sub Seksi Penindakan Keimigrasian}

Melakukan penyidikan dan penindakan, pencegahan dan penangkalan, penampungan sementara orang asing yang melakukan pelanggaran Keimigrasian berdasarkan peraturan perundang-undangan yang berlaku.

\section{k. Kepala Sub Seksi Pengawasan Keimigrasian}

Melakukan pengawasan terhadap WNA yang masuk ke wilayah Republik Indonesia maupun WNI yang akan berpergian ke luar negeri serta mengadakan kerja sama antar instansi yang ada kaitannya dalam bidang pengawasan orang asing berdasarkan peraturan perundang-undangan yang berlaku.

\section{Kepala Seksi Status Keimigrasian}

Mengkoordinasikan pelaksanaan pemantauan status keimigrasian, pendayagunaan warga negara asing pendatang maupun pemukin dan alih status izin tinggal, serta melaksanakan penelaahan dan penilaian tentang status keimigrasian orang asing, pemukim berdasarkan peraturan perundangundangan yang berlaku dalam rangka tertibnya pelaksanaan tugas.

\section{m. Kepala Sub Seksi Penentuan Status Keimigrasian}

Melakukan penyaringan, penelitian, penyelesaian permohonan alih status dan izin tinggal keimigrasian sesuai dengan ketentuan yang berlaku.

\section{n. Kepala Sub Seksi Penelaahan Status Keimigrasian}

Melakukan penelitian terhadap kebenaran bukti kewarganegaraan seseorang dan memberikan surat keterangan orang asing untuk kelengkapan permohonan kewarganegaraan.

\section{o. Kepala Seksi Informasi dan Sarana Komunikasi Keimigrasian}

Melakukan pengumpulan, pengolahan serta penyajian data informasi dan penyebarannya untuk penyidikan keimigrasian serta melakukan pemeliharaan dokumentasi keimigrasian sesuai dengan ketentuan yang berlaku guna kelancaran pelaksanaan tugas Seksi Informasi dan Sarana Komunikasi Keimigrasian.

\section{p. Kepala Sub Seksi Informasi}

Melakukan penyebaran dan pemantauan informasi mengenai WNI yang berangkat ke luar negeri dan orang asing yang masuk ke Indonesia dalam rangka pengamanan teknis keimigrasian. 


\section{q. Kepala Sub Seksi Komunikasi}

Melakukan pemeliharaan dan pengamanan dokumentasi keimigrasian serta menggunakan sarana komunikasi keimigrasian dalam rangka pelaksanaan tugas.

\section{Bagan 1.}

Struktur Organisasi Kantor Imigrasi Kelas I Bandar Lampung

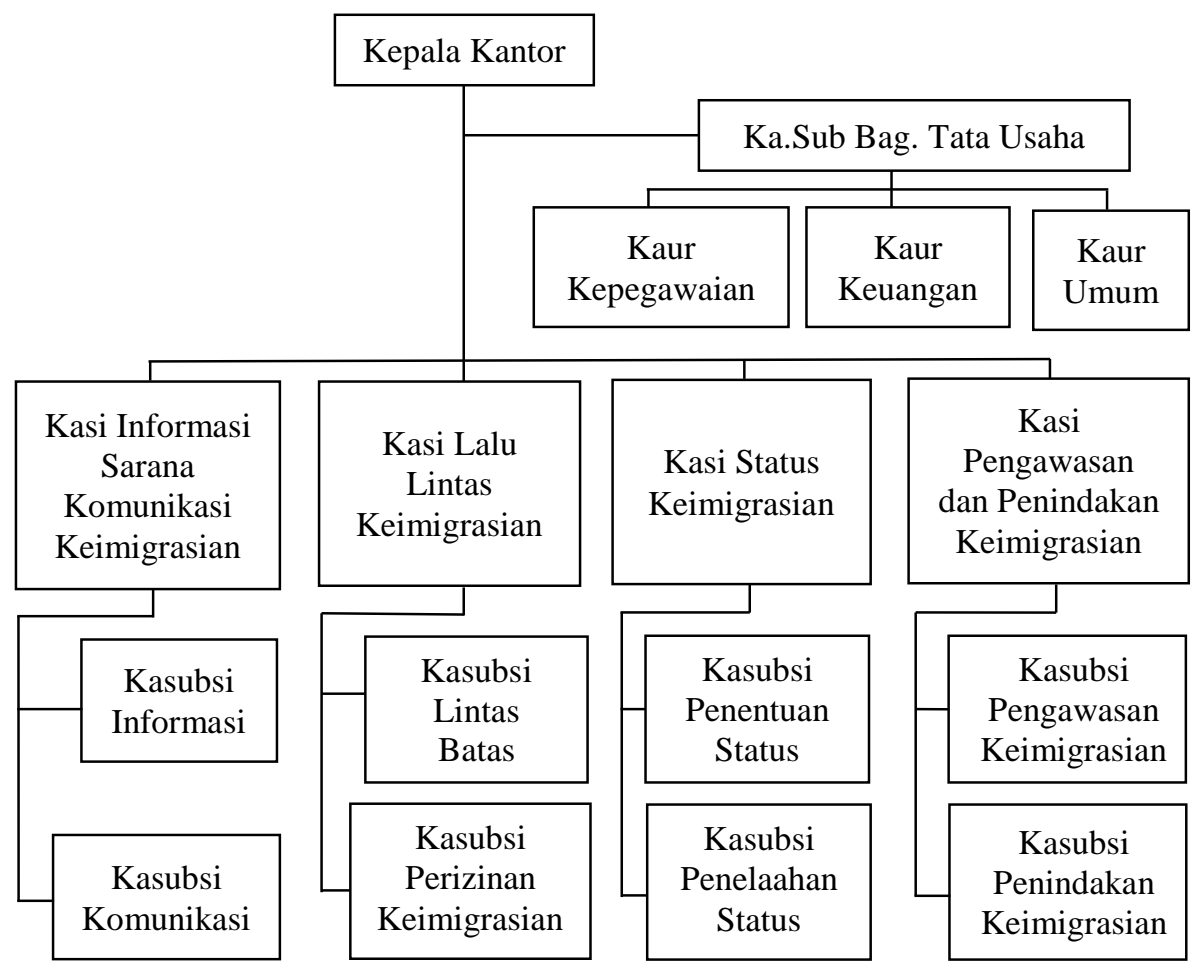

Sumber: Kantor Imigrasi Kelas I Bandar Lampung.

Dalam melaksanakan kegiatan keimigrasian, Kantor Imigrasi Kelas I Bandar Lampung mempunyai visi yaitu: memberikan pelayanan prima dan penegakan hukum keimigrasian secara profesional, sedangkan misinya adalah:

a. menyelenggarakan pelayanan keimigrasian yang cepat, tepat dan terukur dengan memanfaatkan teknologi yang modern;

b. meningkatkan kemampuan SDM dalam rangka pemberian pelayanan yang berkualitas kepada masyarakat serta mengedepankan nilai-nilai dasar martabat dan hak asasi manusia; 
c. mendeteksi secara dini pelanggaran keimigrasian yang akan timbul sebagai ancaman dan gangguan berupa kejahatan guna terlaksananya pembangunan nasional;

d. membangun dan mengembangkan kerjasama dengan instansi terkait dibidang pengawasan dan masyarakat dalam upaya pencegahan hukum keimigrasian.

Kesiapan dan keoptimisan untuk dapat melaksanakan tugas, fungsi, visi dan misi Imigrasi tersebut di atas, tentunya harus ditopang dengan kesigapan seluruh pegawai pada Kantor Imigrasi Kelas I Bandar Lampung dalam melaksanakan tugas-tugasnya. Sumber Daya Manusia pada Kantor Imigrasi Kelas I Bandar Lampung berjumlah 54 orang dengan rincian pada tabel di bawah ini :

Tabel 2.

Struktur Pegawai Kantor Imigrasi Kelas I Bandar Lampung

\begin{tabular}{|l|c|r|r|}
\hline No & Golongan & Struktural & $\begin{array}{c}\text { Non } \\
\text { Struktural }\end{array}$ \\
\hline 1 & IV & 1 & - \\
\hline 2 & III & 14 & 27 \\
\hline 3 & II & - & 12 \\
\hline 4 & I & - & - \\
\hline \multicolumn{2}{|l|}{ Jumlah } & $\mathbf{1 5}$ & $\mathbf{3 9}$ \\
\hline
\end{tabular}

Sumber : Kantor Imigrasi Kelas I Bandar Lampung.

Berdasarkan uraian tersebut di atas dapat diketahui bahwa tugas pokok dan fungsi kantor Imigrasi kelas I Bandar Lampung adalah menyelenggarakan urusan yang berkaitan dengan tugas keimigrasian sesuai dengan peraturan perundang-undangan yang berlaku pada wilayah hukumnya.

2. Penegakan Hukum terhadap Tindak Pidana Penyalahgunaan Izin Tinggal Keimigrasian pada Kantor Imigrasi Kelas I Bandar Lampung

Penegakan hukum merupakan penyelenggaraan hukum oleh petugas penegak hukum oleh orang-orang yang berkepentingan sesuai dengan kewenangan masing-masing menurut aturan hukum yang berlaku. Dalam pelaksanaan tugas keimigrasian, keseluruhan aturan hukum keimigrasian 
harus ditegakkan kepada setiap orang yang berada di dalam wilayah hukum negara Republik Indonesia baik itu warga negara Indonesia (WNI) atau warga negara asing (WNA). Hal ini dimaksudkan untuk membuat jera kepada para pelanggar tindak pidana keimigrasian di Indonesia, khususnya di wilayah Propinsi Lampung. Penegakan hukum keimigrasian ini sangat penting, karena keimigrasian berhubungan erat dengan kedaulatan suatu negara. Dengan adanya penegakan hukum yang tegas, maka integritas dan kedaulatan negara Indonesia secara tidak langsung akan dihormati dan dihargai oleh negara-negara lain.

Penegakan hukum keimigrasian terhadap warga negara Indonesia (WNI), ditujukan pada permasalahan:

a. pemalsuan identitas;

b. pertanggungjawaban sponsor;

c. kepemilikan paspor ganda;

d. keterlibatan dalam pelanggaran aturan keimigrasian.

Penegakan hukum keimigrasian terhadap warga negara asing (WNA), ditujukan pada permasalahan:

a. pemalsuan identitas WNA;

b. pendaftaran orang asing dan pemberian buku pengawasan orang asing;

c. penyalahgunaan izin tinggal;

d. masuk secara ilegal atau berada secara ilegal;

e. pemantauan/razia;

f. kerawanan keimigrasian secara geografis dalam perlintasan.

Berdasarkan hasil penelitian pada Kantor Imigrasi Kelas I Bandar Lampung, menurut Sahedi selaku Kepala Seksi Pengawasan dan Penindakan Keimigrasian, menjelaskan bahwa dalam penyelesaian kasus tindak pidana penyalahgunaan izin tinggal keimigrasian oleh warga negara asing dilakukan dengan 2 cara yaitu tindakan adminstratif keimigrasian (di luar sistem peradilan pidana) dan tindakan projustisia (proses peradilan) yang termasuk di dalam Sistem Peradilan Pidana (Criminal Justice System). Tindakantindakan tersebut diuraikan sebagai berikut: ${ }^{4}$

\section{a. Tindakan Administratif Keimigrasian}

Tindakan (administrasi) keimigrasian, yang mengacu pada UndangUndang Nomor 6 tahun 2011 Tentang Keimigrasian Pasal 1 ayat (31) yaitu sanksi administratif yang ditetapkan Pejabat Imigrasi terhadap orang asing di luar proses peradilan. Undang-Undang Nomor 6 Tahun 2011 Tentang Keimigrasian Pasal 75 ayat (1) menentukan alasan tindakan (administrasi)

\footnotetext{
${ }^{4}$ Hasil wawancara dengan Sahedi, Kepala Seksi Pengawasan dan Penindakan Keimigrasian Kantor Imigrasi Kelas I Bandar Lampung pada 03 November 2015.
} 
keimigrasian bahwa apabila orang asing yang berada di wilayah Indonesia yang melakukan kegiatan berbahaya dan patut diduga membahayakan keamanan dan ketertiban umum atau tidak menghormati atau tidak menaati peraturan perundang-undangan.

Undang-Undang Nomor 6 Tahun 2011 Tentang Keimigrasian Pasal 75 ayat (2) menentukan tindakan (administrasi) keimigrasian yang dapat berupa:

1) Pencantuman dalam daftar pencegahan atau penangkalan;

2) Pembatasan, perubahan atau pembatalan Izin Tinggal;

3) Larangan untuk berada di satu atau beberapa tempat tertentu di wilayah Indonesia;

4) Keharusan untuk bertempat tinggal di suatu tempat tertentu di wilayah Indonesia;

5) Pengenaan biaya beban; dan / atau

6) Deportasi dari wilayah Indonesia.

Kemudian, Ahmad Firmansyah selaku Kepala Kantor Imigrasi Kelas I Bandar Lampung lebih lanjut mengatakan bahwa selain itu berdasarkan ketentuan perundang-undangan yang ada hampir setiap kasus keimigrasian dapat dikenakan Tindakan Administratif Keimigrasian (Deportasi), hal ini terjadi karena kewenangan yang diberikan oleh Undang-Undang sangat luas dan seperti suatu Pasal karet. Penentuan apakah dikenakan Tindakan Keimigrasian ataukah di proses melalui proses peradilan sepenuhnya ditentukan oleh Pejabat Imigrasi di setiap tingkatan struktur organisasi. Kemudian ketidakjelasan sanksi administratif yang diberlakukan terhadap ancaman yang bukan bersifat administratif terjadi secara meluas dalam hal penegakan hukum keimigrasian. ${ }^{5}$

Sebagai suatu instrumen penegakan hukum, Undang-Undang Keimigrasian memuat klausul penangkalan tidak hanya terhadap warga negara asing tapi juga terhadap Warga Negara Indonesia, walaupun proses dan persyaratan untuk menetapkan penangkalan terhadap WNI cukup ketat namun norma tersebut jelas bertentangan dengan Hak Asasi Manusia. Sebagai warga masyarakat dunia yang harus selalu mengikuti norma-norma yang berlaku secara internasional melalui konvensi-konvensi yang ada Undang-Undang Keimigrasian tidak mengatur secara khusus/spesifik terhadap kejahatan yang berdimensi internasional yang dilakukan oleh suatu organisasi kejahatan lintas antar negara (transnational).

Lebih lanjut, Ahmad Firmansyah mengatakan bahwa pada umumnya negara-negara diakui memiliki kekuasaan untuk mengusir, mendeportasi, dan merekonduksi orang-orang asing, seperti halnya kekuasaan untuk

\footnotetext{
${ }^{5}$ Hasil wawancara dengan Ahmad Firmansyah, Kepala Kantor Imigrasi Kelas I Bandar Lampung pada 09 November 2015.
} 
melakukan penolakan pemberian izin masuk, hal ini dianggap sebagai suatu hal yang melekat pada kedaulatan teritorial suatu negara. Mengingat pengaturan mengenai keberadaan dan kegiatan orang asing di suatu negara merupakan esensi kedaulatan teritorial yang melekat pada suatu negara, maka negara berhak menentukan batasan-batasan terhadap keberadaan dan suatu kegiatan yang dapat atau boleh dilakukan oleh orang asing. ${ }^{6}$

Penegakan hukum keimigrasian di mulai dari titik tolak hal ikhwal keimigrasian yang meliputi pengawasan terhadap lalu lintas orang yang masuk dan keluar wilayah negara Republik Indonesia dan pengawasan orang asing di wilayah Indonesia. Pejabat Imigrasi berwenang melakukan tindakan administrasi keimigrasian terhadap orang asing yang berada di wilayah Indonesia yang melakukan kegiatan berbahaya dan patut diduga membahayakan keamanan dan ketertiban umum atau tidak menghormati atau tidak menaati peraturan perundang-undangan. Tindakan administratif keimigrasian dapat berupa:

1) pencantuman dalam daftar pencegahan dan penangkalan;

2) pembatasan, perubahan, atau pembatalan izin tinggal;

3) larangan untuk berada di satu atau beberapa tempat tertentu di wilayah Indonesia;

4) keharusan untuk bertempat tinggal disuatu tempat tertentu di wilayah Indonesia;

5) pengenaan biaya beban;

6) deportasi dari wilyah Indonesia.

Kewenangan untuk menetapkan keputusan tindakan administratif keimigrasian ditingkat operasional ada pada Kepala Kantor Imigrasi, di tingkat pengawasan dan pengendalian ada pada koordinator/bidang imigrasi pada setiap kantor wilayah Kementerian Hukum dan HAM, dan ditingkat pusat dalam hal ini Direktur Jenderal Imigrasi yang dalam pelaksanaannya pada Direktur Penyidikan dan Penindakan Keimigrasian. Walaupun pengaturan mengenai keberadaan dan kegiatan orang asing merupakan instrumen penegakan kedaulatan negara, Undang-undang keimigrasian juga mengatur hak orang asing yang terkena tindakan keimigrasian untuk mengajukan keberatan secara hirarki, hal ini ternyata bahwa undang-undang ataupun hukum keimigrasian juga memperhatikan masalah tersebut sebagai bagian hak asasi manusia.

Tindakan adminstratif keimigrasian yang sering dilaksanakan pada kantor Imigrasi Kelas I Bandar Lampung adalah deportasi. Deportasi adalah tindakan paksa mengeluarkan orang asing dari wilayah Indonesia. Tata cara proses pendeportasian yang dilaksanakan pada kantor Imigrasi Kelas I

\footnotetext{
${ }^{6}$ Hasil wawancara dengan Ahmad Firmansyah, Kepala Kantor Imigrasi Kelas I Bandar Lampung pada 09 November 2015.
} 
Bandar Lampung yaitu: melakukan berita acara pemeriksaan terhadap orang asing yang melanggar peraturan keimigrasian yang didampingi penterjemah, dan juga didatangkan perwakilan dari kedutaan besar orang asing yang bersangkutan sebagai konfirmasi kebenaran identitas orang asing tersebut berupa paspor, melakukan pengecekan keabsahan visa yang dikeluarkan di Kedutaan Republik Indonesia di luar negeri maupun visa yang dikeluarkan pada saat orang asing tersebut tiba di Indonesia, kemudian membuat surat keputusan deportasi.

Keputusan deportasi dikeluarkan oleh pejabat Imigrasi yang berwenang yaitu Kepala Kantor Imigrasi, dan keputusan tersebut harus disampaikan kepada orang asing yang dikenakan tindakan keimigrasian selambat-lambatnya 7 (tujuh) hari sejak tanggal penetapan. Selama orang asing yang dikenakan tindakan keimigrasian tersebut menunggu proses pendeportasian, orang asing tersebut ditempatkan di ruang detensi Imigrasi.

Undang-Undang Nomor 6 Tahun 2011 Tentang Keimigrasian Pasal 1 ayat (34) menentukan bahwa ruang detensi imigrasi merupakan tempat penampungan sementara bagi orang asing yang dikenai tindakan administratif Keimigrasian yang berada di Direktorat Jenderal Imigrasi dan Kantor Imigrasi dan pada Pasal 44 ayat (1) menentukan bahwa setiap orang asing yang berada di wilayah Indonesia dapat ditempatkan di ruang detensi Imigrasi apabila berada di wilayah Indonesia tanpa memiliki izin tinggal yang sah, atau dalam rangka menunggu proses pengusiran atau pendeportasian keluar wilayah Indonesia.

Ruang detensi Imigrasi yang dikenakan terhadap orang asing tidaklah berstatus rumah tahanan negara (rutan), tetapi pengelolaannya termasuk perawatannya terhadap penghuninya dapat disamakan dengan rutan. Hal ini menjelaskan bahwa apabila bukan termasuk kedalam Rumah Tahanan Negara ataupun bentuk penahanan lainnya maka konsekuensi yang akan muncul adalah tidak adanya potongan tahanan yang akan diterima oleh orang asing tersebut atas pengkarantinaan dirinya dalam vonis.

Berdasarkan hasil penelitian di Kantor Imigrasi Kelas I Bandar Lampung, terhadap penanganan warga negara asing yang melakukan tindak pidana penyalahgunaan izin tinggal keimigrasian, dapat disajikan dalam bentuk tabel jumlah kasus tindak pidana imigrasi yang dilakukan dengan tindakan administratif keimigrasian. 
Tabel 3.

Tindak Pidana Penyalahgunaan Izin Tinggal Keimigrasian Tahun 20112015 Dengan Tindakan Administratif Keimigrasian.

\begin{tabular}{|c|c|c|}
\hline No & Tahun & Jumlah Kasus \\
\hline 1. & 2011 & - \\
2. & 2012 & 7 \\
3. & 2013 & 20 \\
4. & 2014 & 7 \\
5. & 2015 & 7 \\
\hline
\end{tabular}

Sumber : Kantor Imigrasi Kelas I Bandar Lampung Tahun 2015

Berdasarkan data tersebut yang bersumber dari Seksi pengawasan dan penindakan keimigrasian, bahwa terhadap kasus tindak pidana keimigrasian yang terjadi antara tahun 2011 sampai dengan tahun 2015, oleh pejabat imigrasi lebih memberikan tindakan secara non justisia. Tindakan yang dilakukan adalah dalam hal ini pendeportasian yang kemudian diberikan tindakan penangkalan terhadap orang asing tersebut untuk tidak masuk ke wilayah Indonesia selama 1 tahun dengan jangka waktu perpanjangan penangkalan maksimal 2 tahun.

Contoh kasus yang pernah terjadi terhadap orang asing yang bernama Chen Qinpeng yang berkewarganegaraan China, Pasport Nomor E58942114 dan Jing Cilu yang berkewarganegaraan China, Pasport Nomor E37538042. Chen Qinpeng dan Jing Cilu telah melakukan tindak pidana keimigrasian, dimana keduanya masuk ke Indonesia melalui Bandara Soekarno-Hatta pada tanggal 16 September 2015 dengan menggunakan Visa on Arrival. Terhadap terdakwa yang telah melakukan tindak pidana penyalahgunaan izin tinggal yang melanggar ketentuan perundang-undangan keimigrasian, karena yang bersangkutan hanya memiliki izin kunjungan dan berlibur tidak untuk bekerja. Namun pada kenyataannya terdakwa berada di Lampung untuk bekerja melakukan pelatihan terhadap karyawan PT. Radema Graha Sarana yang sedang mengerjakan proyek pengeboran untuk pemasangan pipa gas milik PGN di Bandar Lampung. Sehingga terdakwa diduga melakukan pelanggaran keimigrasian sebagaimana dimaksud Pasal 122 huruf a jo Pasal 75 ayat (2) huruf $\mathrm{a}, \mathrm{b}$, dan $\mathrm{f}$ Undang-Undang Nomor 6 Tahun 2011 tentang Keimigrasian dan kepada yang bersangkutan dikenakan tindakan administratif keimigrasian berupa penangkalan, pembatalan izin tinggal, dan pendeportasian.

Menurut Abdulmuthalib Thahar selaku pihak akademisi dalam melaksanakan kerjanya pihak imigrasi harus menegakkan Undang-Undang Nomor 6 Tahun 2011. Terhadap orang asing yang melakukan 
penyalahgunaan visa harus di deportasi. Namun dalam pelaksanaannya seringkali terkendala terhadap biaya terhadap pemulangan orang asing sehingga banyak orang asing yang menumpuk di Rudenim. ${ }^{7}$

Pada saat proses pemulangan orang asing tersebut dilakukan pengawasan keberangkatan oleh petugas Imigrasi sampai ke tempat pemeriksaan Imigrasi, kemudian diterakan tanda penolakan dipaspornya oleh petugas Imigrasi di Tempat Pemeriksaan Imigrasi baik di bandara maupun pelabuhan dan orang asing tersebut dipulangkan.

\section{b. Tindakan Projustisia}

Pegawai Imigrasi pada kantor Imigrasi kelas I Bandar Lampung secara faktual dibagi dalam 2 (dua) jenis kepegawaian yaitu pegawai tata usaha dan pegawai teknis yang disebut pejabat Imigrasi. Pejabat Imigrasi inilah yang dapat berfungsi sebagai penyidik untuk melakukan penyidikan tindak pidana keimigrasian, tetapi tidak semua pejabat Imigrasi dapat disebut penyidik, hanyalah pejabat Imigrasi yang sudah mendapatkan pendidikan di Pusdik Reskrim Polri, Megamendung yang dapat disebut sebagai penyidik. Dalam pendidikan tersebut, PPNS Imigrasi belajar mengenai proses penyidikan tindak pidana keimigrasian.

Tindakan Pro justisia yaitu penanganan suatu tindak pidana keimigrasian melalui proses peradilan, yang termasuk di dalam Sistem Peradilan Pidana. Tindakan secara pro justisia diberikan kepada orang asing yang melakukan tindak pidana atau pelanggaran keimigrasian yang tercantum dalam Undang-Undang Nomor 6 tahun 2011 jo Peraturan Pemerintah Nomor 31 Tahun 2013 Keimigrasian, dilakukan dengan penyidikan terhadap tersangka dan barang bukti yang berkaitan dengan tindak pidana Imigrasi yang dilakukan, melakukan tindakan pertama di tempat kejadian, melakukan tindakan pengkarantinaan terhadap orang asing, melakukan penggeledahan, penyitaan dan pemeriksaan terhadap tempat, benda-benda, dokumen-dokumen, surat-surat yang berkaitan dengan tindak pidana imigrasi, memanggil para saksi dan tersangka, dengan disertai pembuatan berita acaranya disetiap tindakan hukum yang dilakukan.

Warga negara asing apabila kedapatan tertangkap tangan melakukan tindak pidana imigrasi ataupun tindak pidana imigrasi yang berkaitan dengan tindak pidana lainnya maka penyidik dapat secara langsung melakukan tindakan seperti yang diatur dalam KUHAP Pasal 5 ayat (1) huruf b yaitu:

1) pengangkapan, larangan meninggalkan tempat, penggeledahan dan penyitaan;

2) pemeriksaan dan penyitaan surat;

\footnotetext{
${ }^{7}$ Hasil wawancara dengan Abdul Muthalib Thahar, Akademisi Fakultas Hukum Universitas Lampung pada 17 Desember 2015
} 
3) mengambil sidik jari dan memotret seseorang;

4) membawa dan menghadapkan seorang pada penyidik.

Tindakan Projustisia ini dilaksanakan oleh pejabat Imigrasi khususnya Penyidik Pegawai Negeri Sipil (PPNS) Imigrasi. Dimana diberi wewenang oleh Undang-Undang untuk melakukan penegakan hukum keimigrasian terhadap pelanggaran tindak pidana keimigrasian. PPNS Imigrasi melakukan kordinasi dengan penyidik polri dalam hal pemberitahuan dimulainya penyidikan tindak pidana imigrasi kepada penyidik polri selaku koordinator dan pengawas PPNS imigrasi sebagaimana ketentuan dalam KUHAP Pasal 107 ayat (2) dan dalam hal serah terima berkas perkara hasil penyidikan tindak pidana imigrasi dari PPNS imigrasi kepada penyidik polri selaku korwas PPNS imigrasi untuk disampaikan kepada penuntut umum sebagaimana ketentuan dalam KUHAP Pasal 107 ayat (3) dan apabila melakukan penghentian penyidikan maka memberitahukan kepada penyidik polri dari penuntut umum seperti yang ditentukan dalam KUHAP Pasal 109 ayat (3). Penghentian penyidikan dilakukan apabila tidak teradapat cukup bukti, peristiwa tersebut bukanlah tindak pidana dan penyidikan dihentikan demi hukum seperti yang ditetukan dalam KUHAP Pasal 109 ayat (2).

Menurut Sahedi selaku Kepala Seksi Pengawasan dan Penindakan Keimigrasian pada Kantor Imigrasi Bandar Lampung mengatakan bahwa penindakan yang dilakukan terhadap warga negara asing yang melakukan tindak pidana keimigrasian dengan cara memanggil, memeriksa, menggeledah, menangkap atau menahan seseorang yang disangka melakukan tindak pidana keimigrasian. Dimana laporan dari masyarakat terhadap warga negara asing yang melakukan tindak pidana sangat membantu dalam penegakan hukum keimigrasian. Menurut Sahedi, peran serta masyarakat masih sangat sedikit, ini terbukti dari jarangnya laporan masyarakat ke Kantor Imigrasi Kelas I Bandar Lampung terhadap adanya pelanggaran hukum keimigrasian. ${ }^{8}$

Pemeriksaan yang dilakukan merupakan kegiatan untuk memperoleh keterangan, kejelasan dan keidentikan tersangka maupun para saksi dan barang bukti maupun mengenai unsur-unsur tindak pidana keimigrasian yang telah terjadi, sehingga kedudukan ataupun peranan seseorang maupun barang bukti dalam tindakan keimigrasian menjadi jelas dan terang. Dasar pertimbangan dilakukan pemeriksaan adalah laporan kejadian keimigrasian, berita acara pemeriksaan di tempat kejadian perkara, berita acara penangkapan, berita acara karantina imigrasi, berita acara penggeledahan, dan berita acara penyitaan, adanya petunjuk dari Penuntut Umum mengenai adanya pemeriksaan tambahan. Penyelesaian dan penyerahan berkas perkara

\footnotetext{
${ }^{8}$ Hasil wawancara dengan Sahedi, Kepala Seksi Pengawasan dan Penindakan Keimigrasian Kantor Imigrasi Kelas I Bandar Lampung pada 03 November 2015.
} 
adalah akhir dari proses penyidikan tindak pidana keimigrasian. Dilakukannya hal tersebut adalah hasil pemeriksaan tersangka dan para saksi atau saksi ahli beserta kelengkapannya, memenuhi unsur-unsur tindak pidana keimigrasian dan dilakukan demi hukum.

Penyerahan berkas perkara merupakan kegiatan pengiriman berkas perkara yang berkaitan dengan tanggungjawab atas tersangka beserta dengan barang bukti kepada penuntut umum melalui penyidik Polri dalam dua tahap yaitu PPNS Imigrasi menyerahkan tanggungjawab atas tersangka beserta dengan barang bukti. Penghentian penyidikan dilakukan sebagai kegiatan penyelesaian perkara apabila tidak cukup bukti, peristiwa pidana tersebut bukanlah tindak pidana keimigrasian, dan dihentikan demi hukum. Tindakan keimigrasian yang dikenakan secara pro justisia, yang dilakukan dengan berdasarkan pada Undang-Undang Nomor 6 Tahun 2011 Tentang Keimigrasian Pasal 106, terhadap warga negara asing diketahui dari laporan tentang adanya tindak pidana keimigrasian, tertangkap tangan ataupun dengan diketahui sendiri secara langsung oleh PPNS Imigrasi pada saat melakukan pemantauan (operasi) ke lapangan.

Salah satu kasus pelanggaran keimigrasian yang pernah terjadi terhadap orang asing di daerah Lampung yaitu yang dilakukan oleh Marwan Saydeh bin Mustafa, berkewarganegaraan Syriah, bekerja sebagai pemain sepak bola dan beralamat di Apartment Gading Nias Jakarta Utara. Marwan Saydeh bin Mustafa telah memberikan data yang tidak sah atau keterangan yang tidak benar untuk memperoleh Dokumen Perjalanan Republik Indonesia untuk dirinya sendiri. Pada tanggal 28 November 2014 Marwan Saydeh bin Mustafa datang ke Kantor Imigrasi Kelas I Bandar Lampung untuk mengurus pembuatan paspor Republik Indonesia dimana data kependudukannya adalah KTP dan KK palsu. Terhadap terdakwa yang telah melanggar ketentuan perundang-undangan keimigrasian maka dilakukan tindakan kepadanya penahanan Rutan selanjutnya diperpanjang oleh Penuntut Umum pada Kejaksaan Negeri Bandar Lampung. Dengan sanksi pemidanaan tersebut diharapkan dapat menimbulkan efek jera dan menjadi contoh penegakan hukum keimigrasian yang tegas dengan berpegang teguh terhadap Undang-Undang Nomor 6 tentang Keimigrasian, sehingga orang asing yang berada di Lampung lebih taat terhadap aturan yang berlaku di Indonesia.

Berdasarkan penelitian pada kantor Imigrasi Kelas I Bandar Lampung, maka diperoleh rekapitulasi data jumlah tindakan projustisia periode tahun 2011 sampai dengan 2015 sebagai berikut: 
Tabel 4.

Tindak Pidana Penyalahgunaan Izin Tinggal Keimigrasian Tahun 20112015 dengan Tindakan Pro-Justisia

\begin{tabular}{|c|c|c|}
\hline No & Tahun & Jumlah Kasus \\
\hline 1. & 2011 & - \\
2. & 2012 & 1 \\
3. & 2013 & - \\
4. & 2014 & 1 \\
5. & 2015 & - \\
\hline
\end{tabular}

Sumber : Kantor Imigrasi Kelas I Bandar Lampung tahun 2015

Data tersebut di atas yang bersumber dari Seksi Pengawasan dan Penindakan Keimigrasian Kantor Imigrasi Bandar Lampung, bahwa terhadap tindak pidana imigrasi yang terjadi di Wilayah Hukum Kantor Imigrasi Kelas I Bandar Lampung.

Berdasarkan uraian data tersebut di atas, dalam penegakan hukum keimigrasian yang dilaksanakan pada Kantor Imigrasi kelas I Bandar Lampung, tindakan projustisia jarang dilaksanakan, hal ini dikarenakan dirasa tidak efektif, memakan waktu yang relatif lama dalam prosesnya, dan pengalokasian anggaran yang masih belum memadai dan secara merata di semua daerah serta sumber daya manusia PPNS Keimigrasian sangat terbatas jika dibandingkan dengan penyidik Polri. Sehingga Kantor Imigrasi Kelas I Bandar Lampung lebih memilih upaya hukum Non Justisia, melalui upaya hukum administrasi ataupun deportasi ke negara asalnya.

Tujuan dari pengawasan terhadap orang asing yang masuk ke Indonesia adalah dalam rangka menjaga tegaknya kedaulatan negara. Maka dari itu dalam menegakkan Undang-Undang Keimigrasian sebaiknya imigrasi melakukan pengawasan dan monitori terhadap orang asing yang masuk ke Indonesia sejak orang asing berada di bandara maupun di pelabuhan dimana dalam pengecekan visa di paspor lebih teliti dan bila terdapat kejanggalan maupun kecurigaan terhadap orang asing tersebut ada baiknya petugas imigrasi melakukan wawancara dan introgasi terhadap motif dan tujuan orang asing tersebut masuk ke Indonesia.

Kemudian wilayah-wilayah yang akan dikunjungi di data dan dimasukkan ke sistem yang langsung terkoneksi dengan sistem yang terdapat di kantor-kantor Imigrasi daerah tempat dimana orang asing tersebut akan berkunjung. Sehingga apabila orang asing tersebut tidak melaporkan keberadaannya di suatu daerah ke Kantor Imigrasi setempat maka pihak imigrasi tetap memiliki data orang asing yang masuk ke wilayahnya. Dengan adanya data tersebut petugas imigrasi dapat lebih mudah dalam melakukan 
pengawasan terhadap orang asing yang berada di wilayahnya. Dalam pengawasan keterlibatan dan kerjasama antar lintas sektoral harus semakin dipererat, kerjasama dengan pihak kepolisian dapat memperkuat keamanan dan kedaulatan Republik Indonesia. Sehingga terciptalah keteraturan dan orang asing yang taat terhadap Undang-Undang Keimigrasian.

\section{Faktor Penghambat dalam Penegakan Hukum terhadap Tindak Pidana Penyalahgunaan Izin Tinggal Keimigrasian}

Tujuan akhir dari penegakan hukum terhadap tindak pidana penyalahgunaan izin tinggal keimigrasian adalah adanya ketaatan hukum dan keteraturan bagi warga negara asing yang keluar masuk wilayah Indonesia. Untuk mencapai hal tersebut sangat penting sekali bagaimana peran Imigrasi dalam menjadikan warga negara asing yang berada di Indonesia patuh terhadap hukum yang berlaku.

Setiap pelaksaan kegiatan pasti memiliki hambatan-hambatan walaupun telah direncanakan dengan baik, begitu juga penegakan hukum terhadap tindak pidana penyalahgunaan izin tinggal keimigrasian memiliki hambatan-hambatan. Berikut hambatan-hambatan terlaksananya penegakan hukum terhadap tindak pidana penyalahgunaan izin tinggal keimigrasian di Kantor Imigrasi Kelas I Bandar Lampung:

a. Pengawasan serta monitoring terhadap keberadaan orang asing di wilayah Indonesia yang dilakukan oleh aparat Imigrasi masih belum mampu untuk melakukan pengawasan secara maksimal baik untuk mengetahui apa kegiatan maupun keberadan orang asing tersebut. Hal ini dikarenakan jumlah petugas imigrasi dirasa kurang.

b. Kurangnya koordinasi dan kerjasama antar instansi lintas sektoral yang terkait ini khususnya aparat imigrasi sebagai aparat pelaksana dari Perundang-Undangan yang ada.

c. Kurangnya PPNS Imigrasi yang menguasai bahasa asing selain bahasa Inggris. Padahal umumnya orang asing yang diperiksa tidak menguasai bahasa Inggris. Sehingga untuk melakukan pemeriksaan terhadap kasus yang sedang ditangani oleh PPNS Imigrasi terhadap orang asing dari negara tertentu harus memerlukan ahli bahasa atau penterjemah. Hal ini menyulitkan petugas dalam melakukan pemeriksaan. Misalnya saja dalam pemeriksaan WNA asal Afganistan, Cina, Jepang, Mesir, atau negara-negara lain yang tidak terbiasa dengan bahasa Inggris.

d. Terbatasnya jumlah sarana penunjang operasional, seperti dana operasional, alat transportasi, dan komunikasi, serta senjata api yang jumlahnya sangat terbatas. Hal ini menyebabkan tidak maksimalnya kinerja PPNS Imigrasi.

e. Masyarakat Lampung yang bersifat non kooperatif dikarenakan adanya sikap yang kurang peduli dan acuh, rendahnya tingkat pendidikan, 
kurangnya sosialisasi peraturan perundang-undangan dalam masyarakat, adanya faktor kepentingan bisnis dari para pihak yang bersangkutan, dan adanya anggapan dari masyarakat itu sendiri yang terlalu mengagungagungkan setiap hal yang berasal dari negara asing. Partisipasi masyarakat sampai saat ini dirasakan masih sangat rendah. Laporan ataupun pengaduan dari masyarakat mengenai keberadaan atau kegiatan orang asing yang ada disekitarnya masih sangat sedikit. Hal ini seperti dapat disebabkan masyarakat itu sendiri, yang bersikap apatis, atau karena ketidak tahuan akibat belum dilakukannya sosialisasi UndangUndang Keimigrasian sampai kepelosok pedesaan dan kecamatan.

f. Waktu yang relatif lama dalam menyelesaikan berkas perkara. Setiap perkara keimigrasian biasanya membutuhkan waktu minimal 3 bulan untuk menyelesaikan perkara tersebut.

Berdasarkan hasil wawancara selama penelitian pada Kantor Imigrasi Kelas I Bandar Lampung dengan Sahedi selaku Kepala Seksi Pengawasan dan Penindakan Keimigrasian Kantor Imigrasi Kelas I Bandar Lampung mengatakan bahwa keimigrasian dalam hal implementasinya secara operasional telah memenuhi tuntutan perubahan zaman reformasi. Begitu juga dalam sistem hukum, dimana dalam pelaksanaannya telah sesuai dengan prosedur yang sederhana dengan prinsip public accountability yang berlandaskan pada azas transparansi (keterbukaan). ${ }^{9}$ Penegakan hukum keimigrasian tidak berjalan sebagaimana diharapkan tanpa ada Sumber Daya Manusia yang sesuai, sistem hukum yang jelas dan sarana yang memadai, tanpa adanya aparat penegakan hukum yang bermoral dan berintegrasi tinggi maka tujuan dari pembentukan Undang-undang Keimigrasian yang ada tidak akan tercapai secara optimal.

Menurut Sahedi bahwa Kemenkumham saat ini masih kekurangan penyidik Imigrasi dari segi kualitas. Untuk sumber daya manusia kami memang ada, walau sedikit, tapi yang ada belum qualified. Penyidik Imigrasi masih terus belajar kepada kepolisian mengenai tata cara penyidikan yang baik dan benar. Sayangnya Polri terkesan pelit membagi ilmu penyidikannya kepada para PPNS dilingkungan Imigrasi itu. Polri agak jual mahal dengan adanya UU Keimigrasian yang baru ini, mereka seperti tidak mau memberikan ilmunya. ${ }^{10}$

Berdasarkan penelitian dan analisis penulis hambatan dalam penegakan hukum terhadap tindak pidana penyalahgunaan izin tinggal keimigrasian di Kantor Imigrasi Kelas I Bandar Lampung adalah jumlah petugas Imigrasi yang melakukan pengawasan serta monitoring terhadap

\footnotetext{
${ }^{9}$ Hasil wawancara dengan Sahedi, Kepala Seksi Pengawasan dan Penindakan Keimigrasian Kantor Imigrasi Kelas I Bandar Lampung pada 03 November 2015.

${ }^{10}$ Ibid.
} 
keberadaan orang asing dirasa kurang, kurangnya koordinasi dan kerjasama antar instansi lintas sektoral, kurangnya PPNS Imigrasi yang menguasai bahasa asing selain bahasa Inggris, terbatasnya jumlah sarana penunjang operasional dan masyarakat Lampung yang bersifat non kooperatif dimana laporan ataupun pengaduan dari masyarakat mengenai keberadaan atau kegiatan orang asing yang ada disekitarnya masih sangat sedikit.

Solusi untuk mengatasi hambatan-hambatan tersebut di atas yang perlu dilakukan adalah:

a. Pengawasan serta monitoring harus ditingkatkan secara maksimal dengan menambah jumlah petugas imigrasi sehingga dapat melaksanakan pengawasan lebih maksimal.

b. Intensitas pengawasan terhadap orang asing harus ditingkatkan agar orang asing taat terhadap aturan yang berlaku.

c. Meningkatkan koordinasi dan kerjasama antar instansi terkait khususnya kepolisian.

d. Memberikan kursus bahasa asing selain bahasa inggris, agar PPNS Imigrasi tidak kesulitan dalam melakukan pemeriksaan terhadap WNA.

e. Sarana penunjang operasional harus ditingkatkan agar kinerja PPNS Imigrasi lebih maksimal dalam menjalankan tugasnya.

f. Meningkatkan kapasitas, profesionalisme dan integritas PPNS melalui peningkatan sumber daya manusia dalam bentuk seminar, simposium, pelatihan teknis penyidikan serta koordinasi antar lembaga penyidik. Dengan adanya kegiatan tersebut PPNS Imigrasi dapat terlatih dalam menyelesaikan setiap berkas perkara sehingga tidak membutuhkan waktu yang lama proses penyidikan.

g. Perlu adanya sosialisasi terhadap masyarakat Lampung tentang UndangUndang Keimigrasian.

\section{Penutup}

\section{Simpulan}

Berdasarkan hasil penelitian dan pembahasan maka kesimpulan dari penelitian ini bahwa proses penegakan hukum terhadap tindak pidana penyalahgunaan Izin Tinggal Keimigrasian dilakukan dengan dua cara yaitu tindakan administrasi di bidang Keimigrasian dan tindakan projustisia. Pada Kantor Imigrasi Kelas I Bandar Lampung lebih sering terjadi kasus keimigrasian yang penanganannya di selesaikan dengan tindakan administrasi di bidang Keimigrasian. Hal ini terjadi karena dengan penanganan administrasi kasus-kasus keimigrasian dapat terselesaikan tanpa harus diselesaikan dengan tindakan projustisia. Tindakan adminstratif keimigrasian yang sering dilaksanakan pada kantor Imigrasi Kelas I Bandar Lampung adalah deportasi. Tindakan projustisia jarang dilaksanakan, hal ini dikarenakan dirasa tidak efektif, memakan waktu yang relatif lama dalam 
prosesnya, dan pengalokasian anggaran yang masih belum memadai dan secara merata di semua daerah serta sumber daya manusia PPNS Keimigrasian sangat terbatas jika dibandingkan dengan penyidik Polri. Sehingga Kantor Imigrasi Kelas I Bandar Lampung lebih memilih upaya hukum Non Justisia, melalui upaya hukum administrasi ataupun deportasi ke negara asalnya.

Penegakan hukum terhadap tindak pidana penyalahgunaan izin tinggal keimigrasian sering mengalami hambatan dikarenakan jumlah petugas Imigrasi yang melakukan pengawasan serta monitoring terhadap keberadaan orang asing dirasa kurang, kurangnya koordinasi dan kerjasama antar instansi lintas sektoral, kurangnya PPNS Imigrasi yang menguasai bahasa asing selain bahasa Inggris, terbatasnya jumlah sarana penunjang operasional dan masyarakat Lampung yang bersifat non kooperatif dimana laporan ataupun pengaduan dari masyarakat mengenai keberadaan atau kegiatan orang asing yang ada disekitarnya masih sangat sedikit.

\section{Saran}

Berdasarkan kesimpulan di atas, maka penulis akan menyampaikan beberapa saran untuk dapat dijadikan masukan sebagai berikut:

a. Petugas Imigrasi hendaknya meningkatkan pengawasan terhadap keberadaan dan kegiatan orang asing, meningkatkan koordinasi antar instansi terkait khususnya kepolisian, memberikan kursus bahasa asing, meningkatkan sarana penunjang operasional. Dengan adanya peningkatan tersebut diharapkan petugas Imigrasi dapat bekerja lebih maksimal.

b. Tindakan projustisia sebaiknya lebih diefektifkan dalam penegakan hukum terhadap tindak pidana penyalahgunaan Izin Tinggal Keimigrasian, karena dengan adanya sanksi pidana ini diharapkan dapat menimbulkan efek jera kepada pelaku dan orang asing lainnya supaya tidak melakukan tindak pidana imigrasi serupa.

c. Masyarakat Lampung diharapkan mau bekerjasama dengan petugas Imigrasi Kantor Imigrasi Kelas I Bandar Lampung dengan melakukan pengaduan mengenai keberadaan atau kegiatan orang asing yang ada disekitarnya. 


\section{Daftar Pustaka}

\section{A. Buku}

Arif, Moh. (1997). Keimigrasian di Indonesia, Suatu Pengantar. Jakarta: Pusdiklat Departemen Kehakiman.

Halwani, Hendra. (2005). Ekonomi Internasional \& Globalisasi Ekonomi, Bogor: Ghalia Indonesia.

Harold J, Berman. (1996). Latar Belakang Sejarah Hukum Amerika Serikat, dalam Talks on American Law, Random House, Inc, Edisi Indonesia, Ceramah- Ceramah Tentang Hukum Amerika Serikat, diterjemahkan oleh Gregory Churchill. Jakarta: PT. Tatanusa.

Kansil, C.S.T. (2002). Pengantar Ilmu Hukum dan Tata Hukum Indonesia. Jakarta: Balai Pustaka.

Kholiq, M. Abdul. (2002). Buku Pedoman Kuliah Hukum Pidana. Yogyakarta: Fakultas Hukum UII.

Moeljatno. (2005). Azas-azas Hukum Pidana. Jakarta: Rineka Cipta.

Muladi dan Arief, Barda Nawawi. (1998). Teori-teori dan Kebijakan Pidana. Bandung: Alumni.

Poernomo, Bambang. (1983). Asas-Asas Hukum Pidana. Jakarta: Ghalia Indonesia.

Indonesia. Yogyakarta: Liberty.

Prodjodikoro, Wirjono. (2003). Azas-azas Hukum Pidana di Indonesia. Bandung: Refika Aditama.

Rahardjo, Satjipto. (1983). Masalah Penegakan Hukum. Bandung: Sinar Baru.

Ramadhan K.H, dan Yusra, Abrar. (2005). Lintas Sejarah Imigrasi Indonesia. Jakarta: Direktorat Jenderal Imigrasi.

Remmelink, Jan. (2003). Hukum Pidana: Komentar atas Pasal-Pasal Terpenting dari Kitab Undang-Undang Hukum Pidana Belanda dan Padanannya dalam Kitab Undang-Undang Hukum Pidana Indonesia. Jakarta: Penerbit PT, Gramedia Pustaka Utama.

Santoso, M, Iman. (2004). Perspektif Imigrasi Dalam Pembangunan Ekonomi dan Ketahanan Nasional. Jakarta: Penerbit Universitas Indonesia (UI Press). (2007). Perspektif Imigrasi dalam Unite Nation Convention Against transational Organized Crime. Jakarta: Perum Percetakan Negara RI.

Sjahriful, Abdullah. (1993). Memperkenalkan Hukum Keimigrasia. Jakarta: Ghalia Indonesia.

Soekanto, Soerjono. (1983). Faktor-Faktor yang Mempengaruhi Penegakan Hukum. Jakarta: Rajawali. 
. (1986). Pengantar Penelitian Hukum. Jakarta: Rineka

Cipta.

\section{B. Peraturan Perundang-Undangan}

Undang-Undang Nomor 6 Tahun 2011 tentang Keimigrasian.

Peraturan Pemerintah Nomor 31 Tahun 2013 tentang Keimigrasian.

Peraturan Menteri Hukum dan Hak Asasi Manusia Republik Indonesia Nomor 27 Tahun 2014.

Peraturan Menteri Kehakiman Republik Indonesia Nomor M-18-PW-07-03 Tahun 1993. 
